\title{
The effect of implementing information systems on MS Glow
}

\author{
Khotibul Umam $^{a}$, Siti Sofiyatul Fuadah ${ }^{b}$, Asfita Putri Wulandari ${ }^{\text {b }}$, Helmi Lestari Neng Tias ${ }^{b}$, \\ Aditya Putri Kusumab ${ }^{b}$ Hasna Fayza Prasanti ${ }^{b}$
}

${ }^{a}$ Madura State Islamic Institute, Pamekasan, Indonesia,

bepartment of Informatic Engineering, University of Trunojoyo Madura, Bangkalan, Indonesia

\begin{abstract}
A B S T R AC T
Ms Glow is a company engaged in the beauty sector. Ms Glow is a local brand that presents a series of skincare, especially for Indonesian women, which was founded in 2013. Technology is growing very fast as is online sales. This Ms Glow Information System was designed to serve as a promotional medium for Ms Glow and to simplify the online buying and selling transaction process. The design of promotional media also considers the factors that can affect the target market and target audience, so that the desires of potential customers can be identified. The website created can display complete and clear information and contain transaction reports, which sometimes errors occur when processing data. Ms Glow's Information System is a website that makes it easy for shop owners and consumers to make sales transactions, purchase goods and report data. Using easy-to-read fonts, attractive photo images, and choosing the right color. This system is created using the PHP programming language with the MySQL database for data storage. The result of this system is that it can process product information, such as: managing user data, category data, goods data, and the process of purchasing goods transactions. Through this website, it is hoped that Ms Glow as previously mentioned can be implemented and improved.
\end{abstract}

Keywords : Ms Glow, Information System, PHP, Mysql, Website.

Article History

Received 01 December 21

Received in revised form 17 December 21

Accepted 21 December 21

\section{Introduction}

According to Sri Rezeki Candra Nursari(2017) "Technology developments today are growing rapidly and helping human work to be lighter, easier, and faster with the help of computers and internet networks.". Likewise, the process of buying and selling goods and services can now be done online. By using the website to make sales, the products being sold can be seen, anywhere and anytime.

According to Nanda Utama R (2017) "Promoting a product using a website will get many benefits, make it easier to expand information about the products being sold, and be more environmentally friendly and cost effective." Ms Glow is one of the companies engaged in the cosmetics sector which has spread almost all over Indonesia.

In the modern era like today, technology and communication are increasing, here a new innovation is made in the form of the Ms Glow website. The Ms Glow website was created to make it easier for the public, especially Ms Glow consumers, to find out about various kinds of skincare products, especially the latest Ms Glow skincare products, and the Ms Glow website here can help people who want to consult online via WhatsApp and the public and consumers can make purchases online. In addition to make it easier for the public and consumers, Ms Glow's website can also make it easier for companies to make product purchases, promotions, and report data.

\subsection{Purpose} is:

The purpose of making a website selling Ms Glow products

1. Simplify the product sales administration process.

2. Can provide broad product information.

3. Market products more broadly, quickly, efficiently.

\subsection{Scope}

Based on the purpose of writing that has been explained the scope of the underlying research is:

1. The e-commerce model applied is a business to customer (B2C) model.

2. The payment transaction method used is bank transfer.

\subsection{Benefit}

The benefits of this research are :

1. Make it easy for consumers to get information about products, product prices, or buy products available on the website.

\footnotetext{
* Corresponding author.

E-mail address: khotibul.umam@iainmadura.ac.id
} 
2. Assist in the transaction management process.

\section{Method}

\subsection{System Survey and Analysis}

MS Glow Cosmetic not only makes skin white, but also glowing. As a beauty product that is applied to the skin, product safety is the most important thing to pay attention to.

Ms Glow's own products are quite complete for the whole body, from the skin to the face, body to feet. Not only for women's skin care needs, Ms Glow provides products for men and specifically for children's skin care.

\section{A. System Requirements Survey}

The stages in the system requirements survey, that is: observation, interview (interview), documentation.

1) Observation Observation is a research activity in order to collect data related to research problems through the process of direct observation in the field. What will be observed is the MS Glow production process in Malang, East Java.

2) An interview is a conversation carried out by two parties, namely the interviewer who asks questions and the interviewee who provides answers to the questions. Interview was conducted with one of the owners of MS Glow, Shandy Purnamasari.

3) Documentation is used as a data source to test, interpret, predict, and support data. Things that will be documented in this research are the production process and interviews with the owners.

\section{B. System Requirements Analysis}

The Analysis method is a method for describing applications based on components and various functions that aim to identify and evaluate the problems that exist in the system.

System requirements analysis stages:

1) Product functionality analysis

The function of this product is:

a. Users can find out information through the data that has been provided

b. Users can make product purchases from the products that have been provided

c. Admin can view, add, change, or delete the data that has been inputted

2) Analysis of hardware requirements the hardware used is mobile phone, laptop, computer.

3) Analysis of operator needs PT Kosmetika Global Indonesia is a manufacturing company that has been known for a long time in the field of cosmetics and skincare. MS Glow entrusts PT Kosmetika Global Indonesia as its flagship tolling service. MS Glow is a local brand that sells cosmetics, skincare, and body care. MS Glow was founded in 2013 by Shandy Purnamasari and Maharani Kemala. MS Glow is an abbreviation of the brand's motto, namely magic for skin. Its products have received BPOM certificates and
HALAL certificates from the Indonesian government, which are standards for products that are officially circulated and are safe for consumers. Sold at affordable prices, MS Glow products can be enjoyed and reached by all people. Due to the increasing number of consumers of MS Glow products, the production team produces more goods

\section{Result}

From the survey that has been carried out, observations were made in the production department which coincided in the Malang area, East Java by conducting interviews with one of the owners of Ms Glow, Shandy Purnamasari. The results obtained from the product functionality analysis are that users can find out product information through available data, users can make purchases, and admins can view, add, change, or delete data obtained from hardware needs such as cellphones, laptops, and computers. MS Glow entrusts PT Kosmetika Global Indonesia as its flagship tolling service. MS glow is a cosmetic, skincare, and body care that was founded in 2013 by Shandy Purnamasari and Maharani Kemala. Ms Glow already has a halal certificate from an Indonesian government agency and is sold at an affordable price so that it can be reached by all people. Due to the increasing number of consumers of MS glow products, the production team produces more goods.

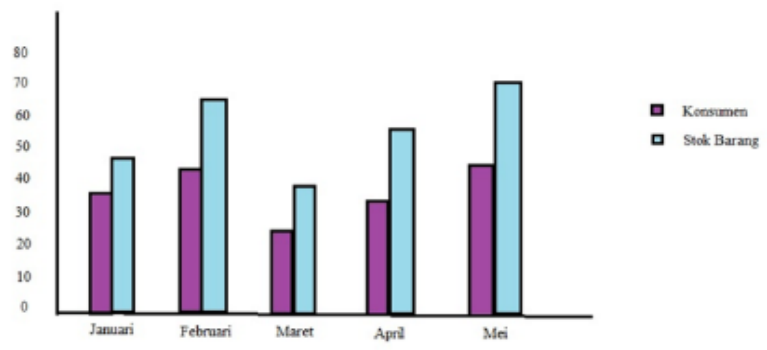

Figure 1. Before using the information system

Before the website was created, the stock of goods was large, but the number of consumers was small due to the lack of information obtained about Ms Glow's products.

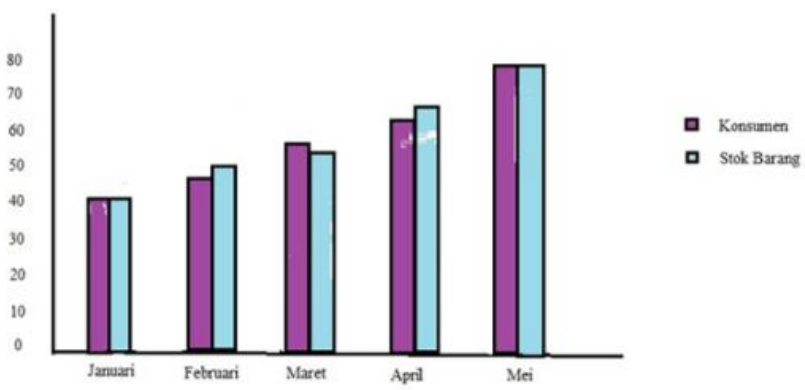


Figure 2. After using the information system

When the website has been created, over time the number of consumers increases and the production of goods also increases. This is because information about the product is already listed on the website and can be read anywhere and anytime.

\section{Conclusion}

Based on the results of research conducted in Malang, East Java on the production process of MS Glow, it can be concluded that:

1. The application of a computerized system to replace manual processes greatly supports the fulfillment of information needs that are relatively fast, precise, and up to date.

2. The process of processing data using computer media is very practical when compared to the manual method, the admin or system operator only needs to see, add, change, or delete data.

From the results of the research conducted, the suggestions that will be concluded include:

1. Improve supervision and control of each data collection process by using reports for decision making.

2. Details on the computer need to be done, so that the personal computer unit is only for operating data collection and not for operating other systems.

\section{REFERENCES}

[1] R Nanda Utama dkk. 2017 Aplikasi Penjualan Online Berbasis Web. Accessed on 15 May 2021 from Pakuan University

[2] Himawan dkk. 2014. Analisa dan Perancangan Sistem Informasi Penjualan Online (E-Commerce) pada CV Selaras Batik Menggunakan Analisis Deskriptif. Accessed on 15 May 2021 from STMIK Raharja
[3] Jufriyanto Moh dkk. 2020 Analysis of Factor that Preferred by Customer in the Selection of Batara Savings Products at BTN Bank Branch Kamal. Accessed on 15 May 2021 from Trunojoyo Madura University

[4] Nursari Sri Rezeki Cadra \& Immanuel Yossela. 2017. Perancangan Sistem Informasi Penjualan Online. Accessed on 14 May 2021 from Pancasila University

[5] Jufriyanto Moh dkk. 2019. Analysis of Service Quality, Trust and Commitment to Customer Satisfaction and Loyalty in Madura Batik Products. Accessed on 17 May 2021 from Trunojoyo Madura University

[6] Juanita Safitri. 2011. Analisa Strategi Bisnis Penjualan Online. Accessed on 15 May 2021 from Telkom University

[7] Listyorini Tri. 2012. Analisis Sistem Penjualan Online Pada Perusahaan Garment Di Semarang. Accessed on 17 May 2021 from from Jurnal Teknik Industri, Mesin, Elektro, dan Ilmu Komputer Muria Kudus Indonesia University

[8] Fauyhi Eko Nugroho. 2016. Perancangan Sistem Informasi Penjualan Online Studi Kasus Tokoku. Accessed on 4 May 2021 from Jurnal Teknik Industri, Mesin, Elektro, dan Ilmu Komputer

[9] Edy Susena, Tekat Budi Santoso. 2020. Sistem Penjualan Online Berbasis Website. Accessed on 4 May 2021 from Politeknik Jambi

[10] Shabur Miftah Maulana dkk. 2015. Implementasi ecommerce sebagai media penjualan online. Accessed on 9 May 2021 from Brawijaya University

[11] Abdi Pandu Kusuma, Kurniawan Agus Prasetya. 2017. Perancangan dan Implementasi E-Commerce untuk Penjualan Baju Online Berbasis Android. Accessed on 9 May 2021 from UNISBA

[12] Arip Aryanto, Tri Irianto Tjendrowaseno. 2013. Pembangunan Sistem Penjualan Online Pada Toko Indah Jaya Furniture Surakarta. Accessed on 9 May 2021 from Sentra Penelitian Engineering \& Edukasi

[13] Faisal Reza. 2016. Strategi promosi penjualan online lazada.co.id. Accessed on 9 May 2021 from Padjadjaran University

[14] Saiful Nur Arif dkk. 2013. Aplikasi Administrasi Perpustakaan Berbasis Web SMK Swasta Brigjend Katamso Medan. Accessed on 9 May 2021 from STMIK Trigunadharma

[15] Astria dkk. 2016. Sistem Informasi Perpustakaan Online Berbasis Web. Accessed on 9 May 2021 from Sam Ratulangi University 